\title{
Impacts of global warming on Japanese agriculture
}

\section{温暖化の日本農業への影響}

\author{
Hiroshi SEINO \\ National Institute of Agro-Environmental Sciences, Tsukuba, Ibaraki 305-8604 JAPAN \\ TEL: +81-298-38-8273 FAX: +81-298-38-8199 E-Mail: hseino@ss.niaes.affrc.go.jp \\ ( Received 3, September 1998 Accepted 17,February 1999)
}

\begin{abstract}
Climate variations significantly affect agriculture through complicated mechanisms. Therefore, agriculture is expected to be especially vulnerable to climate changes. The impacts of climatic warming on agriculture productions are: (1) the direct effects of increased atmospheric $\mathrm{CO}_{2}$ concentration on crop and weed, (2) the indirect effects of climate change on crop, weed, and pests, and (3) the effects of sea level rise on farmland at a low altitude. Thus, in agriculture sector, there are many complex interactions among the related factors. Experimental results, detailed modeling of basic processes, and knowledge of physical and biological processes provide a basic understanding of the direct and indirect effects of climate warming on agricultural production. Experimental results in growth chamber and temperature gradient tunnel are (1) grain yield of rice is generally promoted by high $\mathrm{CO}_{2}$, (2) yields increase $30 \%$ or more with doubled $\mathrm{CO}_{2}$ in the absence of other limiting factors, and (3) rice spikelets have the highest sensitivity to high temperature at anthesis (flowering), and are liable to be sterile due to a failure in pollination, when the flowering temperature is approximately $35^{\circ} \mathrm{C}$. Crop models with climate change scenarios projected by general circulation models predicted the yield changes of crops: (1) rice yield is expected to increase in northern Japan ,but decrease in western Japan, (2) the yield variability would decreases in northern and north-central Japan, but increase in south-central and south-western Japan, (3) maize yield is expected to increase in Hokkaido, but change little in central Japan, and decrease in southwestern Japan, and (4) wheat yield would decrease at all sites.
\end{abstract}

Key Words: global warming, crop production, temperature increase, $\mathrm{CO}_{2}$ concentration

\section{INTRODUCTION}

人間活動に起因する大気中の温室効果ガスの濃度上昇に伴 い、地表面付近の気温が上昇することが懸念されている。農 業は自然環境を利用して生産を行う産業であるため、気候変 動を受けやすい。このため、温暖化は農業に大きな影響を与 えると予想される。ここでは、温暖化の我が国への影響を中 心に述べ、最後に気候変動に関する政府間パネル（IPCC）の 報告書との関連について述べる。

\section{THE GREENHOUSE EFFECTS}

温室効果ガスの濃度が上筆することによって地球が温暖化 するということは、最近、よく認識されてきている。しかし、 ここで温暖化と温室効果は違うものであるということを理解 しなければならない。

Figure1は温暖化のメカニズムを模式的に示したものであ

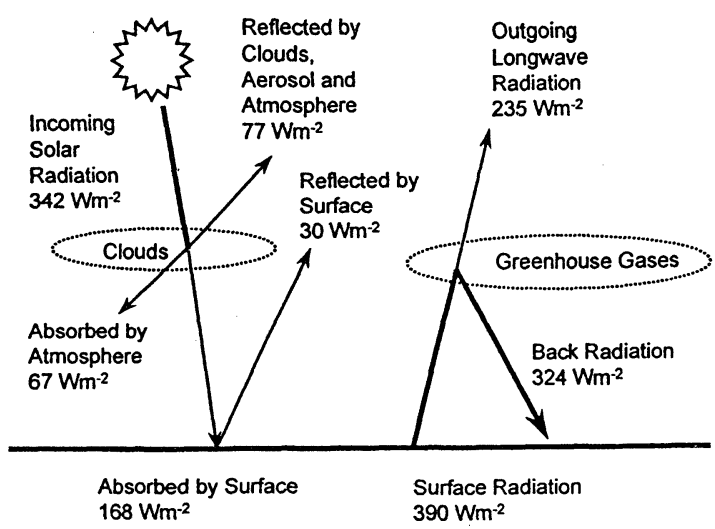

FIG.1 The Earth's radiation balance 
る。太陽の放射は大気を通過し、一部は反射して宇宙空間に 戻る。残りが地表面に達して地表面を暖めている。太陽から 入ってくる放射は波長が短いため、大気中に存在する温室効 果ガス（二酸化炭素、メタン、覀酸化窒素、フロン等）は何 の影響も与えない。一方、地球自身も波長の長い放射を出し ている。地球表面から出る長波放射については、大気中の温 室効果ガスがその一部を吸収して地表面に対して再放射して するという役割を果たしている。このため、地球表面の温度

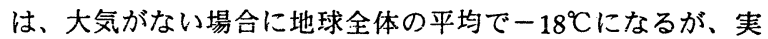
際には大気があり温室効果ガスがあるため+ $15^{\circ} \mathrm{C}$ とる。こ の差の $33^{\circ} \mathrm{C}$ が、地球大気のもつ温室効果であり、それによっ て地球の生命を維持できる快適な環境が整えられていること になる。しかし、最近、この温室効果気体の量が增えている ことが観測で明らかとなってきた。そのため、地球表面に戻 される放射の量が增え、地表面付近の温度が上昇すると予い る。これが現在問題とされている温暖化である。

\section{METHODS OF IMPACT ASSESSMENT}

「気侯変動に関する政府間パネル（IPCC）」では、世界的 に科学者を集めて温暖化について議論し、将来の気候変化の 予測ならびに影響の予測を行っている。1990年に第一次報告 書が、1995年に第二次報告書'が発表された。第一次報告書で は、 2100 年に地球全体の平均気温は $3{ }^{\circ} \mathrm{C}$ 上昇すると予想され たが、第二次報告書では約 $2^{\circ}$ Cに、若干下方修正されている。 農業への影響は、将来の気侯変化がどのように変化するかい う予測が出て、それに基づいて影響評価を行う都合上、第二 次報告書の影響予測結果は第一次報告書レベルでの気侯変化 を基礎としている。

よく知られているように、農業は常に自然を相手にしてい る産業である。そのため、現在でも気侯変動の影響を強く受 けている。したがって、将来予想されているような温暖化が 生じると、農業は大きな影響を受けると予想されている。温 暖化による農業への影響は、大きく三つに分けることができ る。それは、(1)大気中の二酸化炭素濃度が上昇することによ る作物・雑草等の生育・生長への影響、(2)大気中の温室効果 ガス濃度の上昇による気候変化に伴う作物・雑草・病害虫の 生育や生長への影響、(3)標高の低い農地の地下水へ塩分が進 入する影響、である。

温暖化の農業への影響を評価する手法は、二つに大別され る。一つは温暖化した条件（温度、二酸化炭素濃度）を人工 気象室の中で作り出し、そこで作物を栽培することによって 答えを見いだす方法である。もう一つは、作物モテルを使っ て温暖化の条件を与えることによって影響を評価する方法で ある。作物モデルは栽培実験データにもとづいで、作物の生 育・生長と環境要因の関係を数式化したものであり、両者の 評価法は全く独立したものではない。

\section{IMPACT ASSESSMENT BY EXPERIMENT}

水分や盖分などの条件が満たされている場合、二酸化炭素 濃度の上昇は作物の光合成速度を高め、収量や植物体を增加 させると言われている。Figure2に示すように、二酸化炭素濃 度の上昇とともに光合成速度は高まる傾向にあるが、高まり の程度はC 3 作物（イネ、ムギ等）の方がC、作物（トウモロコ シ、サトウキビ等) に比べて大きい。このような反応から、 二酸化炭素濃度が $660 \mathrm{ppm}$ に增えると、たとえばイネの収量は 約 $30 \%$ 增大する。 2.4

また、二酸化炭素濃度が増えるとイネの粒の中に含まれるマ グネシウム含量が隇少しマグネシウムとカリの比率が低くな り、米の品質が落ちるという予想もある。”

一方、作物の生育と温度の関係はFig.3のような関係にある。 この図は作物の生育速度と温度との関係を模式的に示してい る。いずれの作物でも一定の温度以下では生育できないとい う限界温度と、一定の温度以上で生育できないという限界温

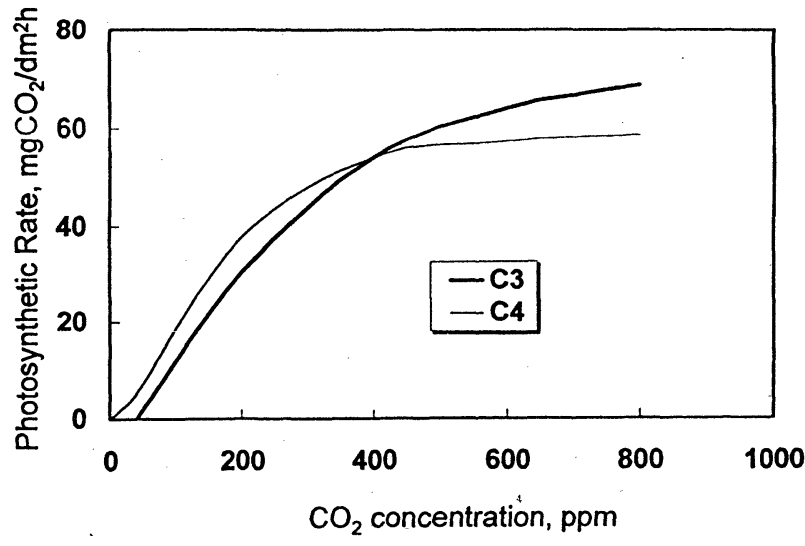

FIG.2 $\mathrm{CO}_{2}$ concentration and photosynthetic rates of $\mathrm{C}_{3}$ and $\mathrm{C}_{4}$ crops

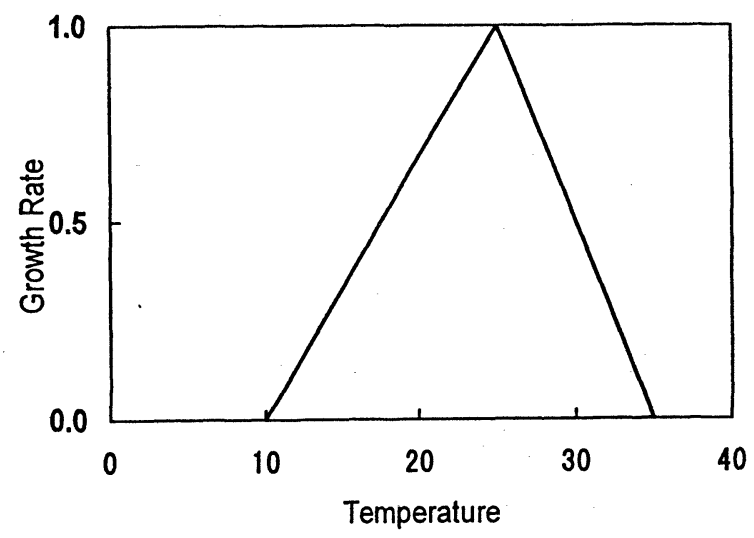

FIG.3 Temperature and crop growth rate

度がある。その中間に最も生育に最適な温度が存在する。通 常は、最適温度のやや低いあたりで栽培されているため、温 度の上昇は一般に生育速度を高める。1 年生の作物では生育 が速まり、生育期間が短くなってしまう。このため、生育期 間中に受け取る太陽エネルギーが減少することになり、光合 成産物の量は減り収量は落ちる。また、イネ頴花は開花期の

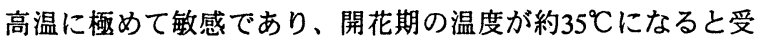
粉障害のため不稔になりやすいといわれている。6.7 イネ穎 花の稔実歩合は、開花期の日最高気温の増加に伴って減少す ることが明らかにされている。

\section{IMPACT ASSESSMENT BY CROP MODELS}

以上のように、二酸化炭素と温度という二つの要因が変化 しただけでも作物への影響は複雑である。上記の結果は、二 酸化炭素の上昇はプラス、気温の上昇はマイナスというょう にみえるが、実際にはこれらの要因が複雑に絡み合い、その 他の要因も加わって温暖化の影響はさらに複雑さを增すこと になる。栽培実験ではあまり複雑な条件設定はできないので、 そのような影響評価には作物モデルが有効となる。

A Prediction of changes in crop yield

作物モデルを使って影響評価をする場合に必要な基本的デ 一夕は気象テータである。一般に、現在の気象デー夕は容易 に得られるが、問題は将来温暖化したときのテータをどうや 
ってつくるかである。現在は、将来の気候変化を予想した大 気大循環モデルの結果（気候シナリオ）から対象地点の気温 ・降水量・日射量の変化を知り、現在の気象テー夕にその変 化量をプラスあるいはマイナスする手法が取られている。モ テルの中では二酸化炭素濃度が 2 倍になることの影響と気候 変化の影響は考虑されているが、雑草や病害虫の変化は考虑 されていない。また、養分、水分に関しては適正に管理され ていると仮定されている。また、現在と同じ栽培管理条件（播 種日、品種等）を仮定している。

我々日本人にとって重要な作物である水稲についての結果 をFig.4に示した。9.11 図中の線は複数の気候シナリオに基づ

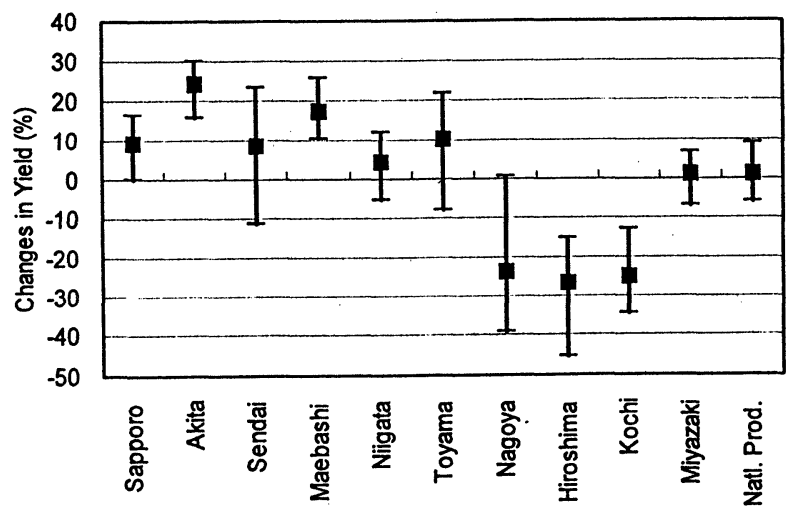

FIG.4 Changes in rice yields

いて得られた収量の変化の幅を示し、中央の点はその平均値 を示している。この結果から、概略的には、北日本では全体 にプラスの影響を受け、西日本ではマイナスの影響を受ける ということができる。四の右端に、各地点の結果を積み上げ て求めた国内生産量が示されている。この結果から、国内生 産量は現状とほぼ変わらないという予想された。収量の年々 変動は、温暖化すると北日本では小さくなり、西日本では逆 に大きくなると予想された。"変動が大きくなるというこ とは、生産が不安定になるということを意味する。これは、 北日本では現在冷夏の影響をしばしば受けて収量の変動が大 きいが温暖化すると収量が安定することを、西日本では高温 障害の影響が出て収量が変動すること意味している。

畑作物ではトウモロコシ、コムギへの影響について研究さ れている。'Figure5に示すように、トウモロコシでは北海道

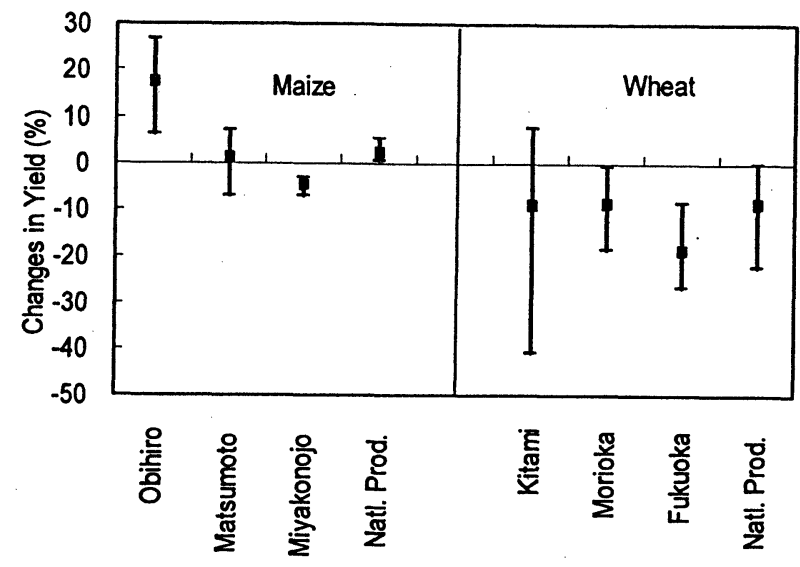

FIG.5 Changes in yields of upland crop
ではプラスになるが、松本はほとんど変化なし、都域では減 収と予想されている。しかし、トウモロコシの栽培面積は北 海道が圧倒的に多いため、国内生産量に変換すると大きく変 化しないと予想された。一方、コムギは北見、盛岡、福岡と も減収すると予想され、これに伴って国内生産量も減ると予 想された。

以上の結果から、水稲とトウモロコシに関しては、国全体 としてはそれほど大きな影響を受けないが、コムギについて は何らかの対策が必要になると考えられる。

\section{B Adaptation to the global warming}

温暖化した場合、変化した気候条件に見合った農業技術が 導入される可能性は十分にある。それらは、新作物の導入、 新品種の導入、播種期の変更、肥培管理法の変更、潅溉シス テムの導入等が考えられる。潅溉システムについては、温暖 化した条件では雨の降り方が非常に大きく変わることが予想 されているがあげられる。現在でも、ここ数年間、雨の降り 方が非常に大きく変わっており、雨が降るときと降らないと きが明確になっている傾向にある。

水稲では新しい品種の導入、12 あるいは、早植えが非常 に効果的にあることが明らかにされている。 シとコムギでは、北海道については非常に有効であるが、そ の他の地域では効果がないと予想された。10 トウモロコシ では、北海道については早植えと潅溉導入は効果が高いと予 想されたが、松本と都域の 2 点については、そのような適応 策を導入しても現状まで回復できないと予想された。10 ムギでは、北見（夏コムギ）については早植えと潅溉の導入 は顕著な効果を示したが、盛岡と福岡（冬コムギ）について は遅植えや潅溉を導入してもほとんど効果がないと予想され た。10

\section{IMPACTS ON THE OCCURRENCE OF INSECTS}

上述したように、作物モテルの中では病害虫、雑草の影響 は全く考虑されていない。その理由は、温暖化の病害虫・雑 草に対する影響評価の研究が進んでいないことである。最近、 温暖化した場合の 4 種類の害虫の世代数の変化が気温一日長 モテルを用いて調べられた。 ${ }^{13}$ たとえば、ニカメイガは現 在九州の南端のみで 3 世代発生できるが、温暖化後は西日本 のほとんどの地域で 3 世代発生可能となる。また、ハスモン ヨトウは現在より広い地域で越冬が可能となると予想されて いる。さらに、ヒラタコクヌスモドキは北方へ分布域を拡大 し、高温耐性の低いスジコナマダラメイカのの分布域南限は北 へ移動し、縮小すると予想された。

\section{CONCLUSION}

温暖化の我が国への影響は、北日本ではプラス、西日本で はマイナスと考えられる。水稲とトウモロコシの国内生産量 は現状を維持できると予想された。しかし、コムギは現状を 維持できないと予想された。また、早植えや潅溉の導入によ って、減収をかなり回復できることが明らかとなった。

一方、我が国は多くの食糧を外国から輸入している。その 意味において、日本国内の生産変動のみならず海外の生産変 動も重要となる。IPCCが取りまとめた世界の農業生産への影 響は次のように要約される。すなわち、二酸化炭素濃度倍增 時の大気大循環モデルによる気候変化のもとでは、地球全体 の農業生産は現在の収量レベルを維持できるが、地域的には かなり変動する。地球規模の農業生産が現状レベルを維持す るということは、一方で人口が100意人に達すると予想され る中、地域的に食糧不足を生じることを意味する。今後とも 気候変化シナリオや作物モテルの改良を含めて、一層の研究 が必要である。 


\section{References}

1 R.B. Watson et al. (eds.): Climate Change 1995. Impacts, Adaptations and Mitigation of Climate Change: Scientific-Technical Analyses, Cambridge University Press 1996.

2 S. Yoshida: Climate and Rice, 211-222 IRRI(Los Banos, Philippines) 1976.

${ }^{3}$ S. Akita: Bull. Natl. Inst. Agric. Sci. (Ser. D), 31: 59-94, 1980.

${ }^{4}$ K. Imai et al.: Japan. J. Crop Sci. 54: 413-418. 1985.

${ }^{5}$ T. Horino: Japan. J. Crop Sci., 59: 605-611. 1990.

${ }^{6}$ T. Satake and S. Yoshida: Japan. J. Crop Sci. 47: 6-17. 1978.

${ }^{7}$ T. Matsui and T. Horie: Japan. J. Crop Sci. 61: 148-149. 1992.

${ }^{8}$ T. Horie: J. Agric. Meteorol. 48: 567-574. 1993.

${ }^{9}$ H. Seino: J. Agric. Meteorol. 51: 131-138. 1995.

${ }^{10} \mathrm{H}$. Seino: Climate Change and Agriculture: Analysis of Potential International Impacts, 293-306 American Society of Agronomy (Madison, USA) 1995.
${ }^{11}$ T. Horie et al.: Modeling the Impact of Climate Change on Rice Production in Asia, 143-164 CAB International (Wallingford, UK) 1995.

${ }^{12}$ T. Horie: The Impact of Climatic Variation on Agriculture, 1. Assessment in Cool Temperate and Cold Regions, 809-825 Kluwer Academic Publishers (Dordrecht, The Netherlands) 1988.

${ }_{13}$ O. Imura et al.: Proc. Int. Insect Diversity Research, Chuncheon, Korea, 44-57. 1993.

著者紹介：清野 豁（せいの ひろし）

1971年 九州大学農学研究科修士課

程修了、九州大学農学部助手、国立

防災科学技術センター研究員、九州

農業武験場研究員、農業環境技術研

究所気候資源研究室長、同企画科長、 同気像管理科長を経て、

琴在、農業環境技術研究所資源・生 態管理科長 